\title{
Paleocurrent Analysis of Upper Cretaceous Zagros Foreland Basin: A Case Study for Tanjero Formation in Sulaimaniya Area NE-Iraq
}

\author{
Kamal H. Karim \\ Department of Geology \\ College of Science \\ Sulaimaniya University
}

\author{
Ali M. Surdashy \\ Department of Geology \\ College of Science \\ Salahaddin University
}

(Received 29/10/2004 , Accepted 26/1/2005)

\begin{abstract}
Tanjero Formation is an Upper Cretaceous (Campanian-Maastrichtian) unit, which crops out within the Imbricated and High Folded Zones in Northeastern Iraq. Its outcrop stretches as narrow northwest-southeast belt near and parallel to the Iranian border. The formation mainly consists of alternation of clastic rocks of sandstone, marl and calcareous shale with occurrence of very thick conglomerate and biogenic limestones.

In this study many sedimentary structures are found in the Tanjero Formation, which have paleocurrent importance. These structures are cross bedding interference ripple marks, imbricated pebbles, elongate rudist and belemnite, plant debris, sole marks, valleys and channels. Most of these structures are found in the lower part. The paleocurrent analyses, as revealed by these structures, are presented in rose and stereonet diagrams, which show south and southwest directions.

\section{تحللل النيارل الفيمة لحوض الفورلاند الهصر الكربنلي الاعل: رلميسية حالة لتكون

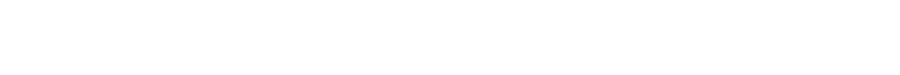

\section{الماخص}

ان تكوين تانجيرو عبارة عن وحدة صخرية تعود إلى الكريتلني الأعلى (كلمبانيان -ملستريختيلن) وققع مكلثفه ضمن ظطق الترلكب والطيت العالية فيشملشرق العراق. تمتد مكلثفه كظاق ضيق باتجهشمل غرب-جذوبشرق على امتداد الحدود الايرلنية. يتكون التكوين بصورة رئيسية من تعلقب الصخور الفتاتية

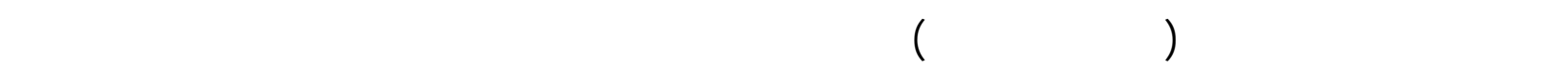

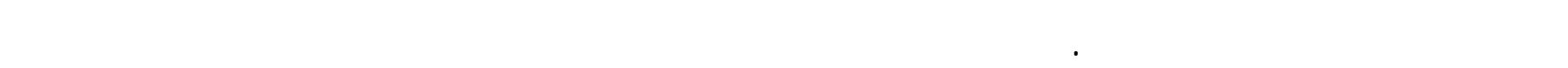

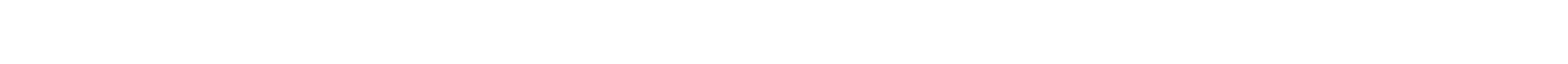
العرضية والمتدلخلة والمتحجرات الطويلة والحصوات المترلكبة وترلكيب للمطوح للسفلية والركلم النباتي
\end{abstract}


والوديلن و القنوات القديمة. لستخمت هذه الترلكيب (خاصة التركيب لحادية الاتجل) لإيجاد اتجه التيار

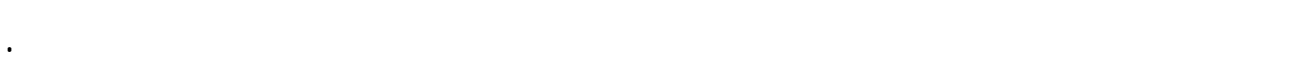

\section{INTRODUCTION}

Tanjero Formation, as an Upper Cretaceous (Campanian-Maastrichtian) unit, exposed within both Imbricated and High Folded Zones in Northeastern Iraq (Buday, 1980 and Buday and Jassim, 1987). It elongates along Iran-Iraq border as narrow and northwestsoutheast belt (Fig.1). The formation mainly consists of clastic sediments, which includes sandstone, marl and calcareous shale with occurrence of very thick conglomerate and biogenic limestones (Bellen et al., 1959). Jaza (1992) studied the sedimentology and environment of the formation and found several facies of turbidite.

On the basis of main lithological attributes, Karim (2004) has divided the formation into three parts (lower, middle and upper parts). The lower part consists of thick succession of conglomerate and sandstone (100-400 m) at near shore area and basin respectively. The middle part (middle transgressive part) is composed of 100-300 m of bluish white marl and calcareous shale. The upper part $(60-200 \mathrm{~m})$ consists of alternation of biogenic limestone and calcareous shale with minor amount of sandstone and conglomerate. He concluded that lower and upper parts have been deposited in relatively shallow water areas while the middle deposited in the deep one.

\section{PALEOCURRENT ANALYSIS}

As for paleocurrent analysis, most of the sedimentary structures, discussed by Karim (2004), are exploited as well as the types of the sedimentary rocks. According to these variables the paleocurrent direction is indicated accurately to be mainly toward south and southwest direction.

The variables used for indication of the paleocurrent direction are as follows:

\section{Type of sedimentary rocks:}

From the facies distribution map of Upper Cretaceous can be realizes that the reefal limestones (Aqra-Bekhme Formation) are mainly located at northwest of the main basin of Tanjero and Shiranish Formations. The occurrence of these limestones at west and northwest of the basin is an indirect indication that paleocurrent direction is not toward northwest or west as mentioned before. This is because the reefs could not survived turbidity of water moving along this paleocurrent direction. The contrasts of direction with previous studies are possibly due to the fact that all of them were conducted on the distal part of the basin the paleocurrent direction is not much clear or may have dispersed directions. (Al-Rawi, 1981, Saadalla and Hassan, 1987 and Jaza, 1992)

\section{Grain size and facies change:}

The change of the grain size from coarse (conglomerate) to fine (sandstone and shale) is generally toward southwest; this is also compatible with facies change. The coastal and 


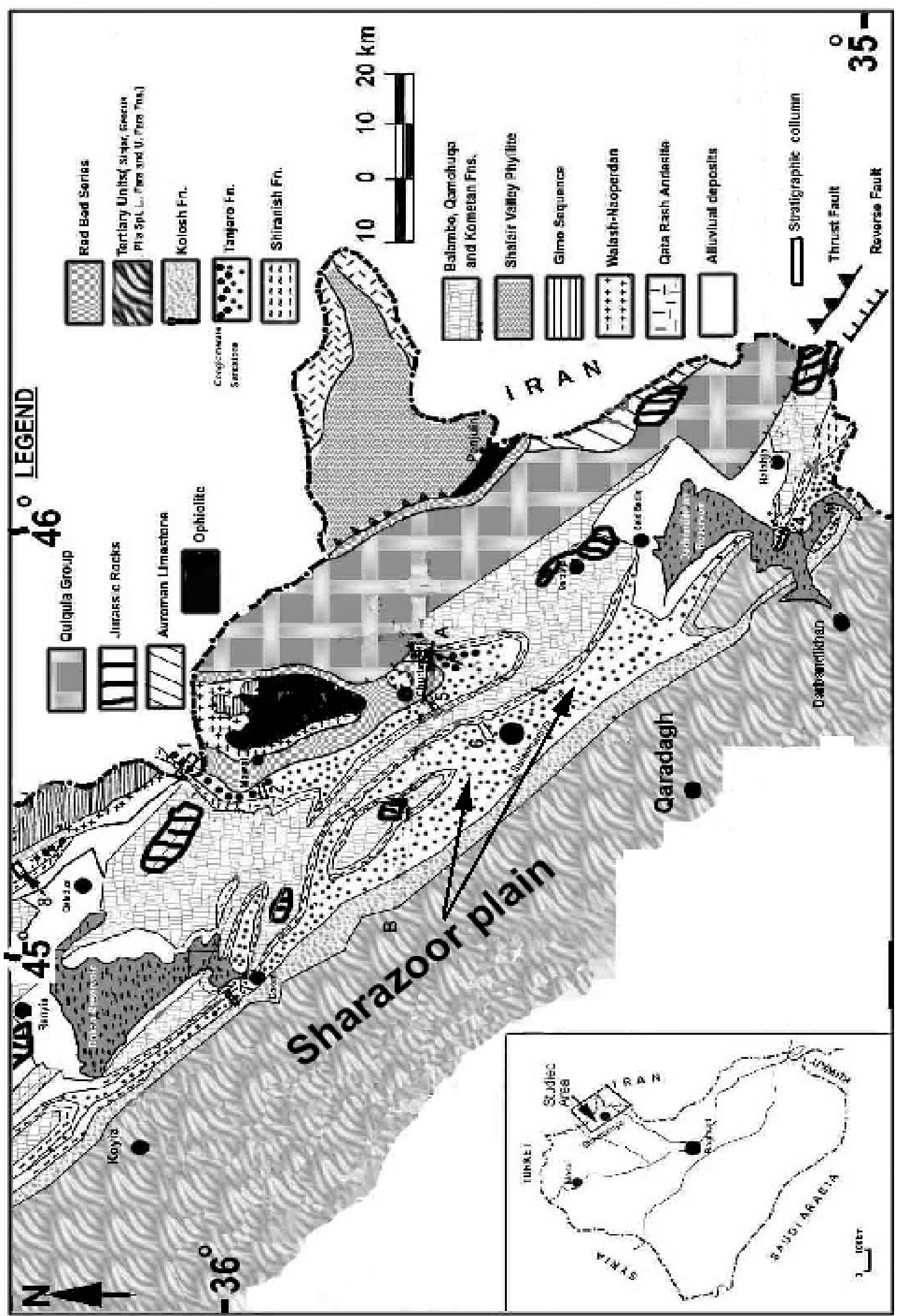

Fig.1: Geological map of the studied area (modified from Jassim and Al-Hassan, 1977). 
shallow facies changing to deeper ones in the same direction of grain size change. The paleoslope dictated direction of grain size and facies changes. This in turn parallels the incised valleys and associated submarine channels, in addition to the southwest elongation of the conglomerate (see Karim, 2004). In a one cases the conglomerate (inside and incised valleys and associated submarine fan) extend and thin out from Chuarta area to Sharazoor plain in nearly southwestern and southern direction, toward basin direction (Fig.2).

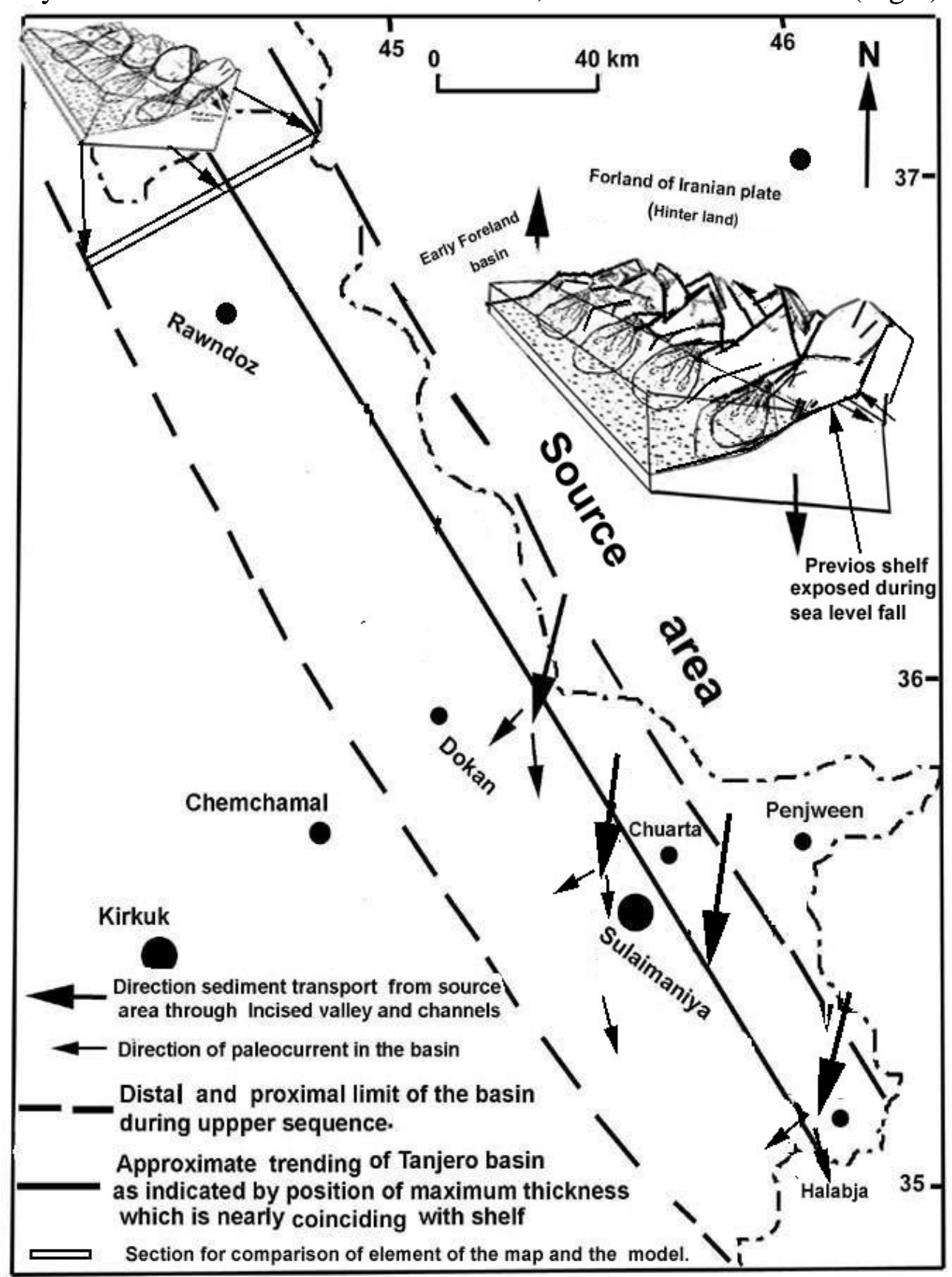

Fig.2: General basin trend and paleocurrent direction of Tanjero Formation during upper sequence. 


\section{Thickness of the sediments:}

The maximum thickness (2000m) of the formation is recorded in the type section in Sirwan valley (Fig.3). In Chuarta area it reaches $1500 \mathrm{~m}$ while in Dokan area is only 630m and thins northwestward to about 50m. This general increase of thickness toward southeast (Sirwan section) is indirect evidence that the paleocurrent direction is toward south and southwest. In other sides the isopach and accommodation maps of Upper Cretaceous, as drawn by Minas (1997, p.89 and 92) show the thickest sediments and the deepest basin in the area south of the studied area especially, the east and northeast of Baghdad City.

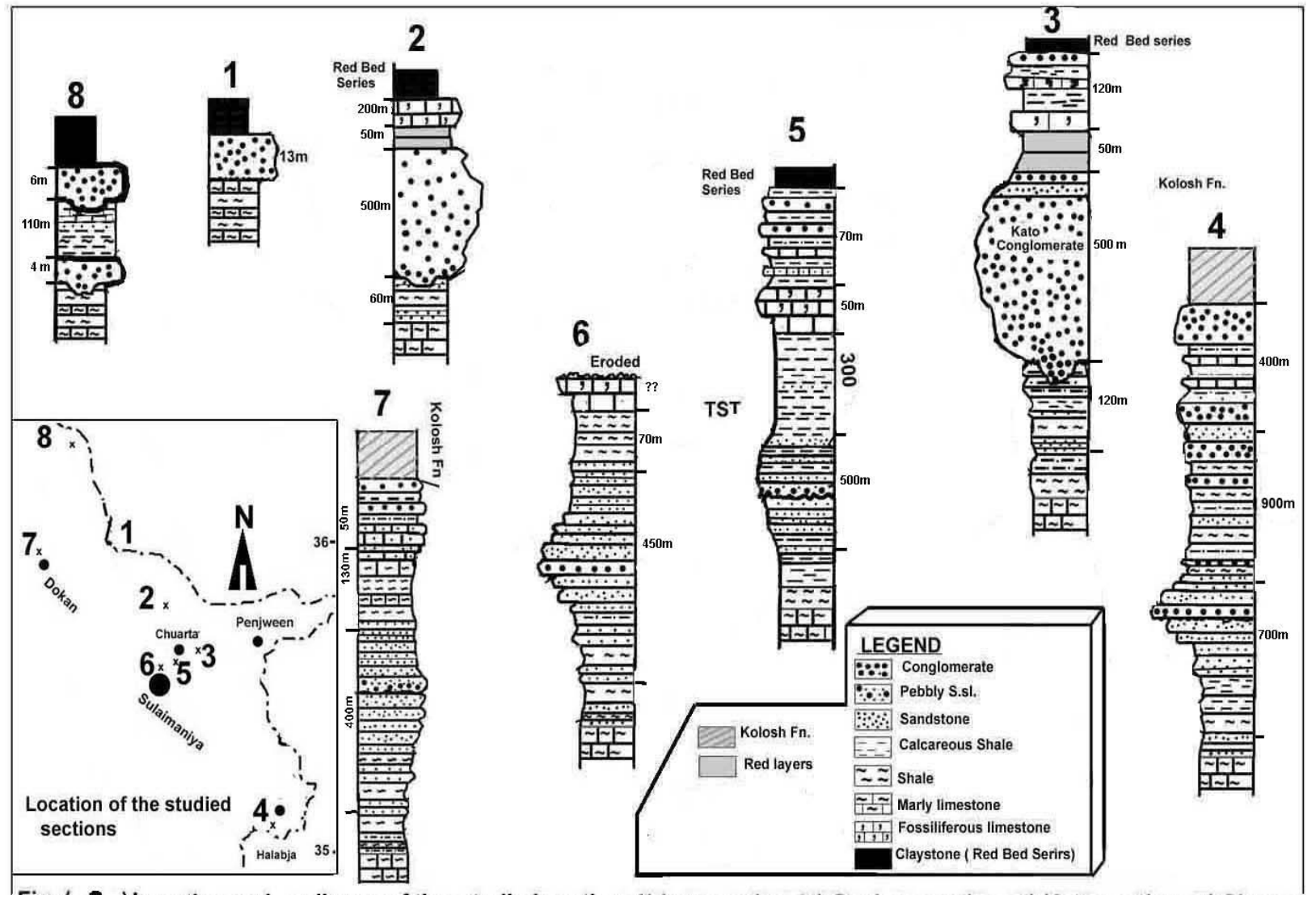

Fig.3: Location and column of thr studied section. 1-Iran section, 2-Qashan section, 3-Kato section, 4-Sirwan section, 5-Tagaran section, 6-Malkandi section, 7-Dokan section, 8Kometan village section (Qandil mountain toe).

(After Karim, 2004).

\section{Unidirectional Sedimentary Structures:}

They are those structures, which indicate one direction of flow (vectorial direction), and have unique direction and take one value of 0 to 360 degrees. The most important unidirectional sedimentary structures, in Tanjero Formation, are imbricate pebbles, cross bedding, asymmetrical ripple marks and flute casts. 


\section{Ripple Marks:}

The interference ripples marks are very common in the north and northwest of Sulaimaniya city, in the lower part of the formation, where one can see tens of them at different horizons (Plate 1.1). These ripple marks occur in the lower part of the formation. The peak of these structures is mainly pointing toward S65W (Fig.4B). Similar ripples exist in the upper part of the formation in Dokan area, on the right bank of the Qashqully stream and north of Qulka village. These ripples are more or less resembling linguoidal ripples. Pettijohn and Potter (1964) termed these ripples interference ripples. The interference ripple marks recorded by Ainsworth and Crowley (1994), they attributed these types of ripple marks to storm deposit (tempestite).

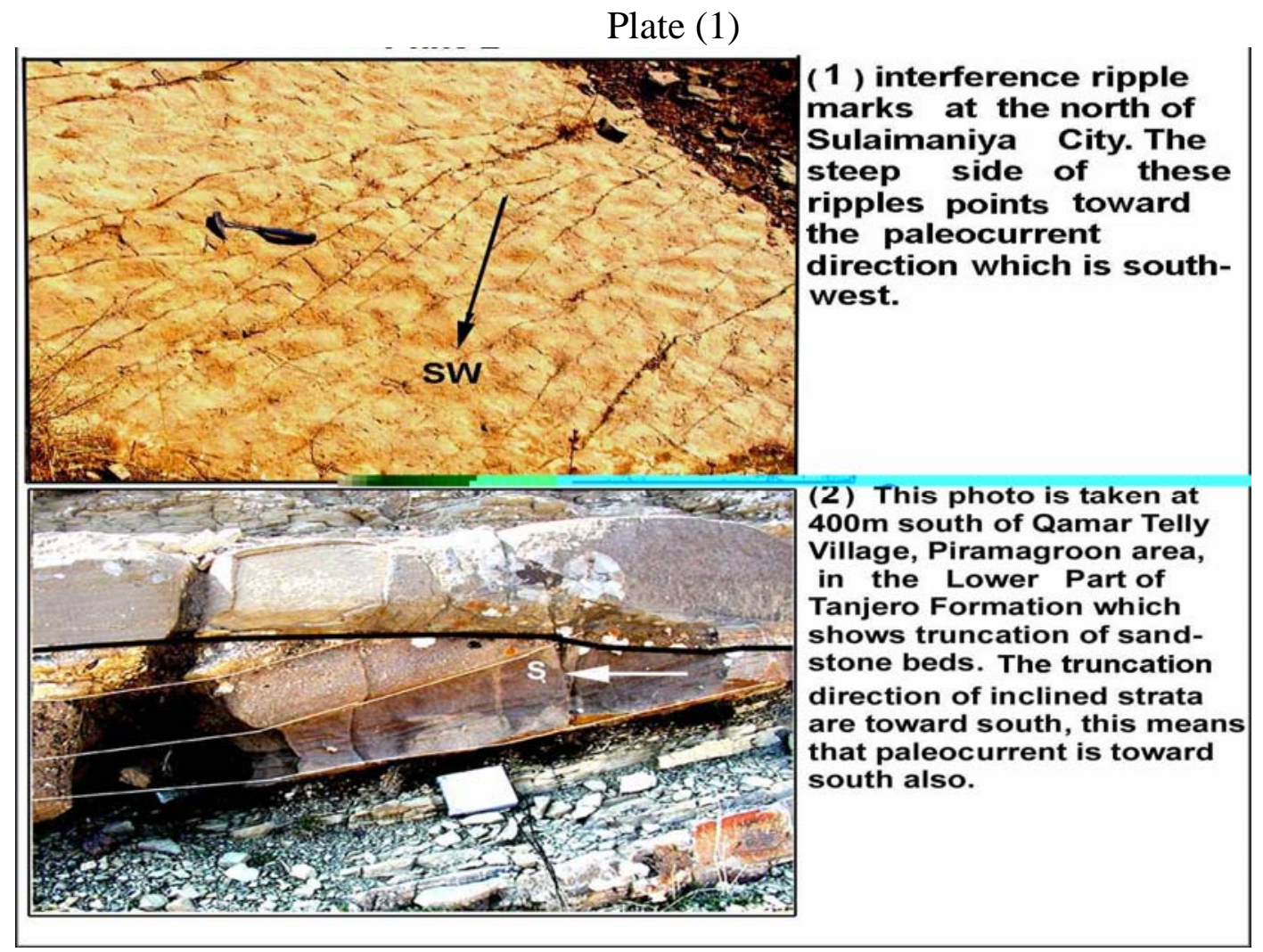

\section{Imbricated pebbles:}

The most important and abundant unidirectional structures in the Tanjero Formation are imbricated pebbles. They exist in the conglomerate of the lower part of the formation in the proximal area at Chuarta-Mawat and Qandil mountain areas. Nearly more than $60 \%$ of the imbricate pebbles in the conglomerate succession (Plate 2) are directed toward south. The other ones may have any direction but mostly bearing toward southwest. These structures can be seen as preferred orientation of elongate fragments (pebbles) at angle to the underling bedding. 


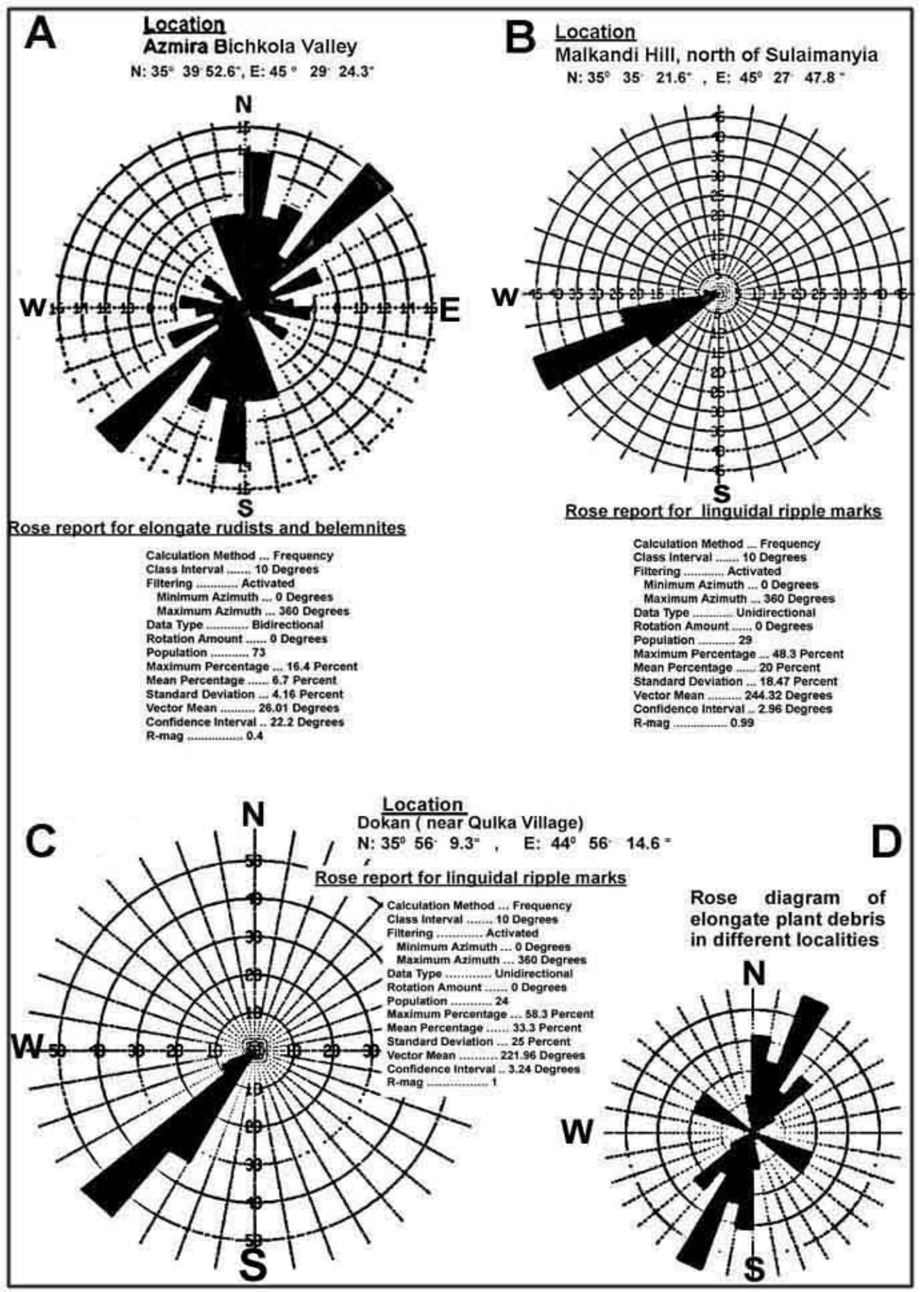

Fig.4: Rose diagram drawn by PC when the data in the tables (1 and 2) entered. The general direction of paleacurrent is southwest. 


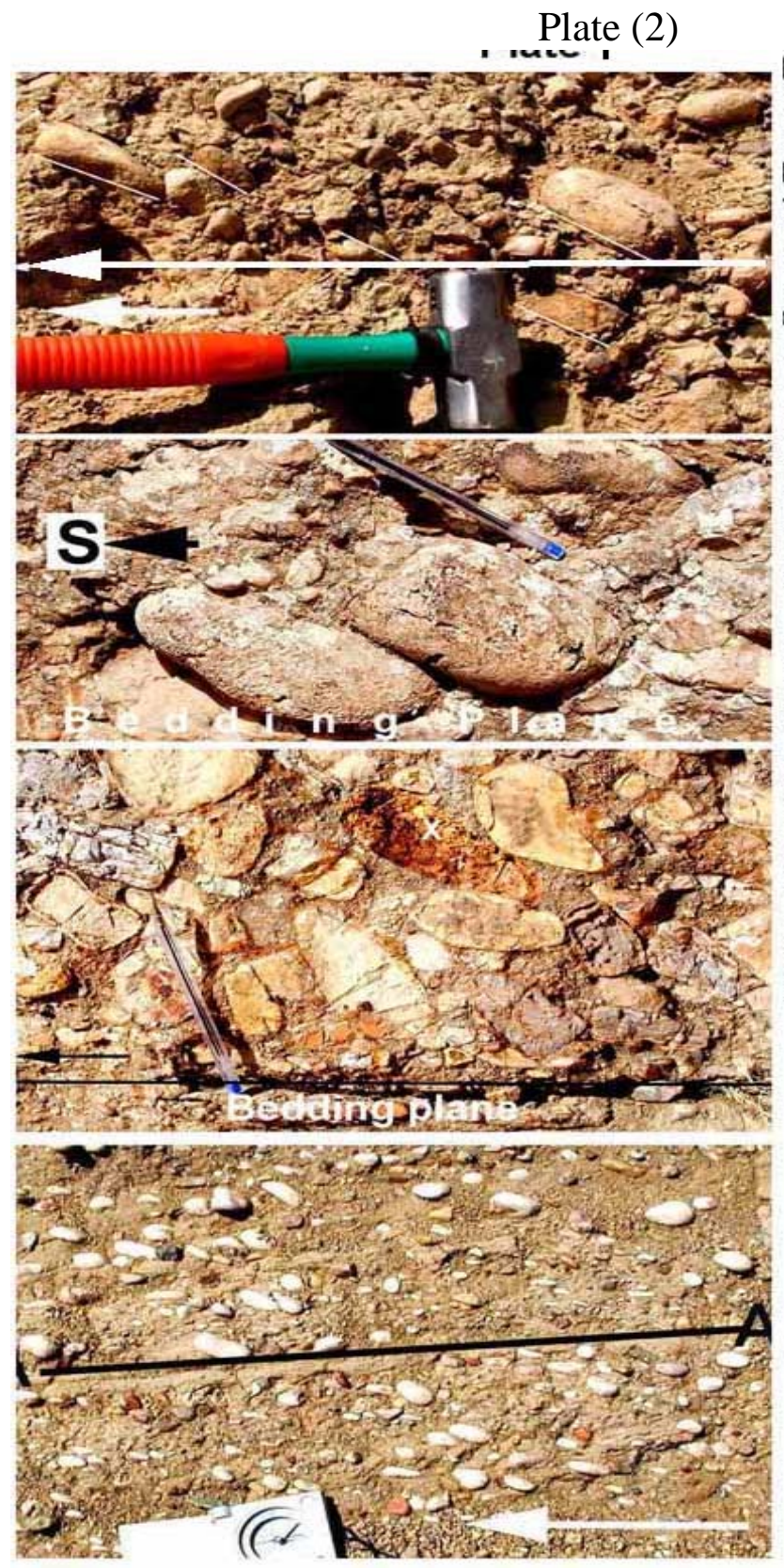

(1) Imbricated chert pebbles in Kato Conglomerate near Qashan Brigde, east of Mawat Town.The white long line and short ones indicate bedding plane and angles of imbrication respectively. The white arrow shows paleocurrent direction ( south)

(2) Imbrication of chert pebbles of Kato Conglomerate at Kato mountain about $1.5 \mathrm{~km}$ south of Kanito village east of Chuarta Town.

$\mathrm{N}: 35^{\circ} \quad 39-15.4=$ E: $45^{\circ} 36^{-} \quad 26=$

(3) About 20 imbricated chert and one limestone $(X)$ pebbles at the $2 \mathrm{~km}$ west of Kanito Village showing paleocurrent direction of S10W.

N: $35^{\circ} 38^{\circ} 56.4^{=}$

$\mathrm{E}: 45^{\circ} 36^{-} 0.5^{=}$

(4) Imbrication of limestone and chert pebbles in the last conglomerate beds at the top of the type section about $1.5 \mathrm{~km}$ south of Nawar village $10 \mathrm{~km}$ southeast west of Halabja Town. A-A is a bedding plain used as a base line for measuring imbrication pebbles. The arrow indicate southern dirction( paleocurrent)

This structure is common on streambeds where flowing water tilts the pebbles under the effect of upper flow regime near the bottom of the stream. The flat surfaces of these pebbles dip upstream. In these areas, the attitudes of tens of these pebbles are measured by compass (plunge angles and directions) and arranged (Table 3).

\section{Bi-directional sedimentary structures:}

The bi-directional sedimentary structures are those, which have two opposite directions indicating only line (or sense) of movement not unique direction. Each of these structures has direction ranging from zero to 180 degrees. The observed structures are as follows: 
Table 1: Azimuth of elongate plant debris measured in different localities such as Mokaba, Chaqchaq valley, Qamartelly Village (foot hill of Piramagroon), Dokan area and Makandi Hill. All five columns are entered into the PC as one continuous column when RockWare Program is used.

\begin{tabular}{|l|l|l|l|l|}
\hline 90 & 210 & 110 & 180 & 186 \\
135 & 214 & 110 & 180 & 190 \\
140 & 220 & 126 & 187 & 198 \\
130 & 190 & 117 & 186 & 200 \\
139 & 195 & 120 & 180 & 205 \\
151 & 112 & 177 & 206 \\
154 & 200 & 115 & 176 & 200 \\
167 & 112 & 185 & 209 \\
167 & 200 & 112 & 190 & 210 \\
163 & 200 & 123 & 170 & 211 \\
170 & 90 & 124 & 196 & 207 \\
183 & 93 & 220 & 184 & 208 \\
181 & 90 & 220 & 222 & 211 \\
178 & 230 & 226 & 122 & 217 \\
167 & 240 & 230 & 209 & 200 \\
189 & 230 & 233 & 206 & 205 \\
210 & 234 & 228 & 199 & 208 \\
\hline
\end{tabular}

Table 2: 1. Athimuthal compass reading of 72 elongate rudist and belemnite body fossils at Azmira Bechkola Valley (N: $35^{\circ} 39^{-} 52.6^{=}$, E: $45^{\circ} 29^{-} 24.3^{=}$) Fossils. 2. Azimuth of 29 linguidal ripple marks at Malkandi Hill (N: $35^{0} 35^{-} 21.6^{=}$, E: $\left.45^{0} 27^{-} 47.8^{\circ}\right)$, 3. 2. Azimuth of 24 linguidal ripple marks at Dokan area $\left(\mathrm{N}: 35^{0} 56^{-} 9.3^{-}\right.$, E: $44^{0} 56^{-}$ $\left.14.6^{=}\right)$.

\begin{tabular}{|l|l|l|l|l|l|l|l|l|}
\hline \multicolumn{2}{|l}{ 1. Elongate body fossil } & \multicolumn{2}{l|}{$\begin{array}{l}\text { 2. Linguidal ripple } \\
\text { mark (Malkandi) }\end{array}$} & \multicolumn{2}{l|}{$\begin{array}{l}\text { 3. Linguidal ripple } \\
\text { Mark (Dokan) }\end{array}$} \\
\hline 50 & 360 & 61 & 3 & 308 & 240 & 234 & 220 & 220 \\
42 & 5 & 33 & 8 & 348 & 240 & 233 & 221 & 216 \\
316 & 73 & 5 & 296 & 345 & 260 & 243 & 217 & 224 \\
90 & 5 & 65 & 42 & 25 & 250 & 247 & 230 & 223 \\
60 & 340 & 20 & 25 & 5 & 270 & 244 & 218 & 215 \\
20 & 39 & 55 & 45 & 89 & 240 & 240 & 226 & 228 \\
70 & 18 & 352 & 10 & 4 & 240 & 245 & 219 & 224 \\
11 & 65 & 10 & 12 & 345 & 235 & 250 & 227 & 217 \\
12 & 48 & 355 & 5 & 350 & 250 & 252 & 221 & 225 \\
90 & 45 & 88 & 31 & 90 & 255 & 230 & 217 & 215 \\
29 & 44 & 45 & 45 & 300 & 240 & 235 & 224 & 222 \\
8 & 66 & 49 & 29 & 295 & 245 & 250 & 225 & 230 \\
360 & 45 & 5 & 38 & 348 & 240 & 252 & & \\
90 & 355 & 355 & 20 & 80 & 235 & 246 & & \\
& & 360 & 354 & 345 & & 245 & & \\
\end{tabular}


Table 3: Compass reading of plunge azimuth (Left column) and angle of Plunge (right column) of imbricated pebbles of conglomerate at: 1.Malkandi Hill (N: $35^{0} 35^{-}$ $21.6^{=}$E: $\left.45^{0} 27^{-} 47.8^{=}\right)$, 2.Damerkan, Arbat (N: $35^{0} 27^{-} 22.4^{=}$E: $45^{0} 29^{-} 57.1^{=}$), 3.Qashan Bridge, Mawat ( $\mathrm{N}: 35^{0} 51^{-} 24^{=} \mathrm{E}: 45^{0} 24^{-} 29.3^{-}$). These data are given as entered into the PC to draw rose diagram (see fig. 3).

\begin{tabular}{|c|c|c|c|c|c|}
\hline \multicolumn{2}{|c|}{1} & \multicolumn{2}{|c|}{2} & \\
\hline Azimuth & Plunge angle & Azimuth & Plunge angle & Azimuth & Plunge angle \\
\hline 20 & 63 & 40 & 43 & 9 & 40 \\
\hline 10 & 52 & 40 & 32 & 8 & 60 \\
\hline 5 & 32 & 25 & 22 & 352 & 31 \\
\hline 240 & 51 & 357 & 41 & 348 & 48 \\
\hline 45 & 22 & 45 & 22 & 355 & 60 \\
\hline 225 & 35 & 335 & 25 & 358 & 55 \\
\hline 345 & 45 & 355 & 35 & 4 & 56 \\
\hline 350 & 33 & 150 & 23 & 11 & 49 \\
\hline 310 & 55 & 340 & 45 & 10 & 38 \\
\hline 314 & 43 & 344 & 33 & 11 & 32 \\
\hline 5 & 30 & 75 & 20 & 360 & 35 \\
\hline 5 & 35 & 145 & 35 & 351 & 41 \\
\hline 280 & 54 & 330 & 44 & 347 & 52 \\
\hline 20 & 34 & 131 & 30 & 14 & 30 \\
\hline 90 & 64 & 160 & 44 & 15 & 35 \\
\hline 270 & 43 & 356 & 33 & 9 & 30 \\
\hline 280 & 70 & 333 & 40 & 5 & 29 \\
\hline 280 & 60 & 344 & 40 & 355 & 33 \\
\hline 280 & 46 & 355 & 36 & 357 & 39 \\
\hline 10 & 60 & 30 & 40 & 360 & 20 \\
\hline 12 & 34 & 82 & 24 & 4 & 27 \\
\hline 14 & 52 & 44 & 42 & 20 & 30 \\
\hline 350 & 33 & 350 & 33 & 15 & 43 \\
\hline 50 & 75 & 150 & 55 & 10 & 34 \\
\hline 12 & 43 & 42 & 43 & 50 & 31 \\
\hline 260 & 66 & 340 & 44 & 340 & 25 \\
\hline 290 & 60 & 330 & 30 & 3 & 37 \\
\hline 50 & 51 & 55 & 41 & 7 & 31 \\
\hline 14 & 44 & 24 & 44 & 310 & 49 \\
\hline 330 & 55 & 342 & 45 & 330 & 28 \\
\hline 280 & 67 & 351 & 37 & 5 & 18 \\
\hline 280 & 44 & 320 & 34 & 351 & 39 \\
\hline 10 & 34 & 30 & 34 & 349 & 70 \\
\hline 325 & 63 & 335 & 53 & 9 & 65 \\
\hline 352 & 53 & 352 & 43 & 10 & 22 \\
\hline 330 & 34 & 339 & 24 & 350 & 35 \\
\hline 325 & 66 & 325 & 51 & 20 & 18 \\
\hline 280 & 54 & 320 & 45 & 7 & 40 \\
\hline 170 & 47 & 21 & 37 & 353 & 34 \\
\hline 150 & 56 & 21 & 36 & 150 & 33 \\
\hline & & & & 180 & 22 \\
\hline & & & & 88 & 29 \\
\hline
\end{tabular}




\section{Elongate rudist and Belemnite fossils:}

Elongate Rudist and Belemnite fossils are found together in the same bed in the upper part of the formation at Chuarta area. In this area the mixed carbonate-siliciclastic succession (see Karim, 2004) is well developed. The lowest limestone bed, at some locality, composed entirely of a stack of elongate rudist and belemnites body fossils. Their length range between $10-25 \mathrm{~cm}$ (Plate 3.1) and they have straight shell or slightly curved. Their directions are generally toward southwest.

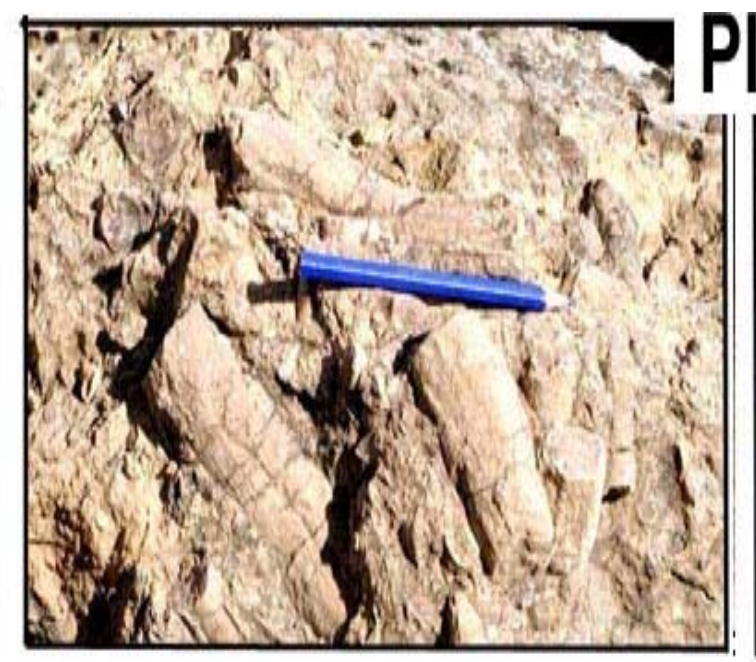

(1) Elongate rudist, parallely arranged as response to effect of paleocurrent, at Upper part of Tanjero Formmation, Chuarta area.

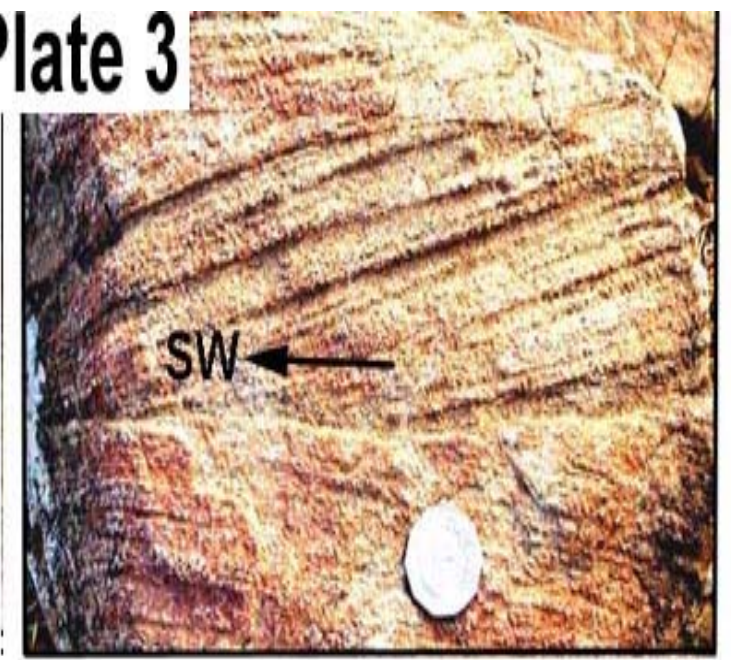

(2) Cross bedding in the lower part of the formation at $2 \mathrm{~km}$ north of Sulaimaniva City, indicates southwest paleocurrent direction.

\section{Plant Debris:}

Their paleocurrent significance is less important than above-mentioned directional structures, because:

1-They are transported into the basin during the river flooding. But most of the debris are deposited at the end of the storm when the energy is too weak that they take no certain directions.

2- As they are normally elongate so they indicate two opposite direction (i.e.not one direction of movement) of the paleocurrent. Potter and Pettijohn (1977) mentioned that plant fragments indicate only line movement of paleocurrent. However, at many localities compass reading of plant debris are taken and their direction are plotted on the rose diagram (Fig.4).

\section{Channel and valleys:}

The channels and valleys in the coastal area of the formation are anisotropic in structures, as they have imbricated pebbles in the upcurrent direction and their length is directed toward paleoslope. These erosional structures have least width in the direction of the paleocurrent. These two characteristics can be used for indication of paleocurrent and 
paleoslope. Several small channels and valleys are found; their imbricated pebbles and length show southwest paleocurrent direction (Plate 2.1, 2.2 and 2.3).

\section{Stereonet- and rose-diagram plotting:}

For the plotting data of the unidirectional and bi-directional sedimentary structures (terminology cited by Sinclair, 1994), a Windows based RockWare program is used as follows:

1- The trends (strikes) of bi-drectional structures are measured as compass quadrant readings. The trend must be measured by using both ends of the compass needle in the two northern or southern quadrants. Lorenz et al. (2002, p. 509) also used this method for same purpose. Then they changed to their equivalent azimuthal readings for entering the PC to draw rose diagram (Fig.5).

2- The effect of tectonic tilt is corrected, by using stereonet where the tilt is more than 30 degrees. Potter and Pettijohn (1977, p.374 and Tucker 1988, p.41) gave this limit for tilt correction and they mentioned that tilt, below 30 degrees needs no correction. Most localities of the studied area have dip amount less than 30 degrees such as, lowland of Chuarta-Mawat area, Sharazoor-Piramagroon plains, Dokan area and Chaqchaq valley, while Kato Mountain and Sirwan Valley have more than 30 degrees of tilting.

3-The attitude (plunge angle and direction) of unidirectional (imbricated pebbles) (Plate 2.1 and 2.2) are measured in the field using compass method. Then, they are plotted on the Schmidt stereonet (Fig.5) by carefully treating for the options given by the Streofile of the RockWare program. The data must be formatted either according to Dip Direction or according to Right Hand Rule. In the present study, the compass readings are arranged (or converted) to azimuthal data by using Dip Direction Format.

4- The flute cast and cross bedding have fewer occurrences than imbricate pebbles. So that they are used in field to support and confirm the direction shown on the stereonet (Fig.5). Cross bedding and laminations have more dispersed direction but the more obvious ones give southwest and south direction.

5- Ripple marks, elongate fossil shell, plant debris are numerous in the lower part and upper part of the formation. So measurement is made on these directional structures. The azimuths of these structures are plotted on the rose diagram using Rose files of RockWare program (Fig.4). The option of "full rose" and "bi-directional" are given to the program when the bi-directional sedimentary structures are entered while for unidirectional ones "half rose" and "unidirectional" option is activated (Fig.4).

6- The over all paleocurrent directions, inferred in this study, are plotted on the map of the studied area (Fig.2).

7- Many structures are photographed in their original position with indication of their azimuth. These photos gave a powerful evidence for the direction of paleocurrent (Plate 2). The clearest photos are taken at the Sirwan valley for imbricated pebbles at the near boundary with Kolosh Formation. At this place the plunging (dipping) of the platy pebbles are so clear that one cannot find similar ones in gravels of recent rivers and alluvial fans (Plate 2.4) which show south direction. Another place, which show clear eyewitness paleocurrent direction, is a very good developed channel filled with conglomerate at the Kato Mountain. There, visual inspection of imbricated pebbles inside 
the channel without any calculation can easily prove the southern direction of paleocurrent at this location (Plate 2.2). But it is possible that the so-called " Qulqula Conglomerate Formation” may have close relation with conglomerate of lower sequence, which deposited at least $10 \mathrm{~km}$ far from the upper one. The study of this conglomerate may reveal farther and better paleocurrent study during lower sequence.

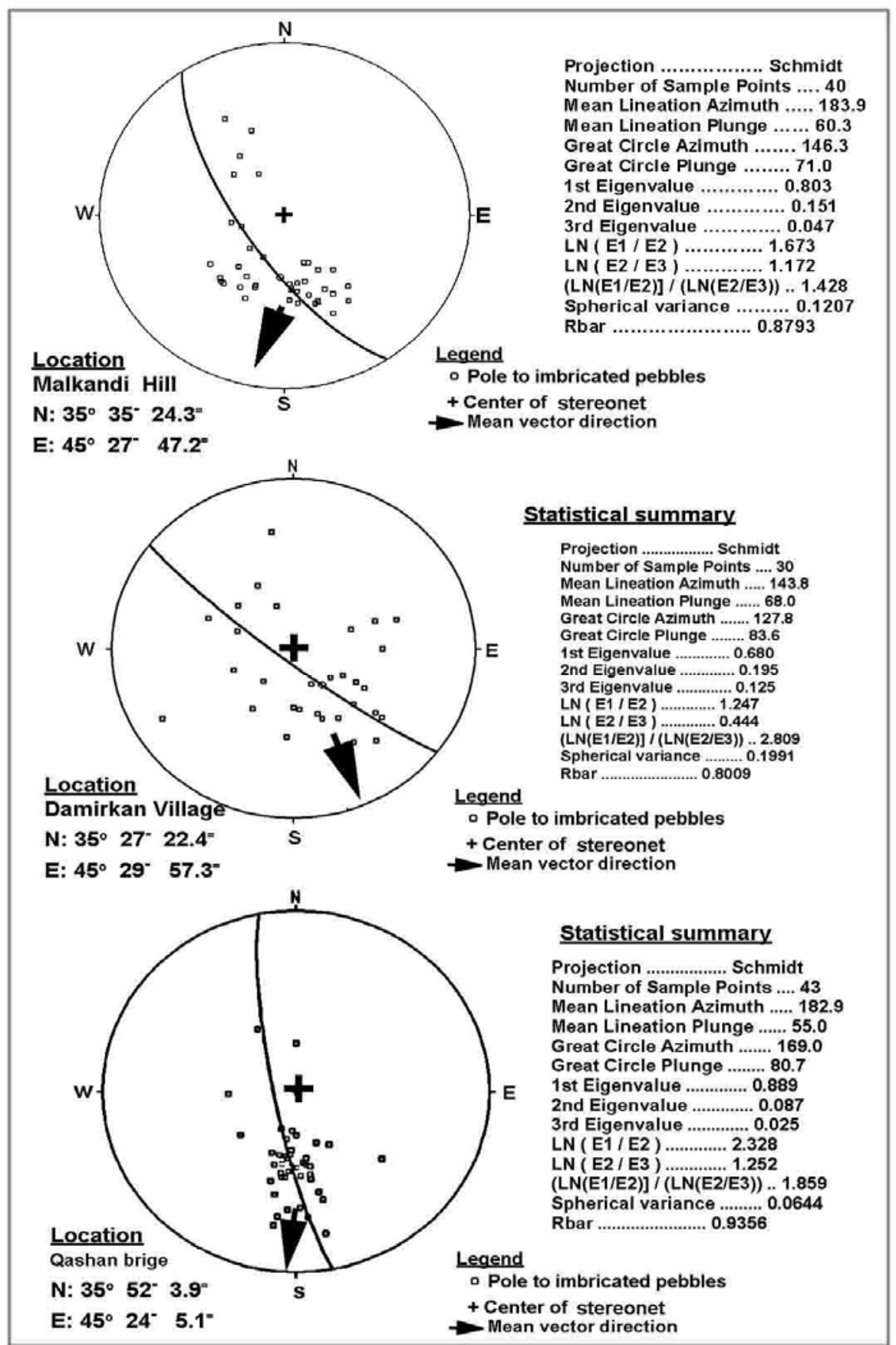

Fig.4: Stereonet diagram showing paleocurrent direction of imbricate pebbles of three localities on the outcrop of Tanjero Formation. 
The paper has the following results:

\section{CONCLUSIONS}

-In this study many sedimentary structures are found, which are not recorded in the Tanjero formation in previous studies such as large scale cross bedding, interference ripple marks, imbricated pebbles, elongated rudist and belemnite plant debris, sole marks and channels.

-The direction of these structures are studied and recorded in the field to be used for paleocurrent indication for basin of Tanjero Formation. The data are processed by PC using Rockware program.

-The paleocurrent is inferred to be toward south and southwest.

-The result is shown by rose and stereonet diagrams in addition to the field photos and maps.

\section{REFERENCES}

Ainsworth, R.B. and Crowley, S.F. 1994. Wave-dominated near shore sedimentation and "forced” regression: post abandoned facies, Great Limestone Cyclothem, Stainmore, UK. Journal of the Geological Society London, Vol.151, pp.681-695.

Al-Rawi, I.K., 1981. Sedimentology and Petrology of Tanjero Clastic Formation in north and northeastern Iraq. Unpublished Ph.D. Thesis, University of Baghdad, 295p.

Bellen, R.C. Van, Dunnington, H.V., Wetzel, R. and Morton, D., 1959. Lexique Stratigraphique, Interntional. Asie, Iraq, vol. 3c. 10a, 333 p.

Buday, T., 1980. In: Regional Geology of Iraq, Vol. 1, Stratigraphy, I.I. M. Kassab and S.Z. Jassim (Eds) D. G. Geol. Surv. Min. Invest. Publ., 445p.

Buday, T. and Jassim, S.Z., 1987. The Regional geology of Iraq: Tectonism Magmatism, and Metamorphism. I.I. Kassab and M.J. Abbas (Eds), Baghdad, 445 p.

Jassim, S.Z. and Al-Hassan, 1977. Petrography and Origin of the Mawat and Penjuin Igneous Complexes. Jour. Geol. Soc. Iraq, Special Issue, on 4th Iraqi Geol. Conf., Baghdad.

Jaza, I.M., 1992. Sedimentary facies analysis of the Tanjero Clastic Formation in Sulaimaniya district, northeast Iraq. Unpubl. M. Sc. thesis, Salahaddin University, 121p.

Karim, K.H., 2004. Basin analysis of Tanjero Formation in Sulaimaniya area, NE-Iraq. Unpublised Ph. D. thesis, University of Sulaimania University, 135p.

Lorenz. J.C., Sterling, J.L., Shecheter, D.S. and Lensen, J.L., 2002. Natural fracture in the Spraberry Formation, midland Basin, Texas: The effects of mechanical stratigraphy on fracture variability and reservoir behavior. AAPG Bulletin, Vol.86, No.3, pp.505 -524.

Minas, H.A.A., 1997. Sequence stratigraphic analysis of the Upper Cretaceous succession of Central and Northern Iraq. Unpubl. Ph. D. thesis, Univ. Baghdad. 188p.

Pettijohn, F.J. and Potter, P.E., 1964. Atlas and Glossary of Primary Sedimentary Structures. Springer-Verlag, Berlin, New York, 370p, 117 plates.

Pettijohn, F.J., 1975. Sedimentary Rocks. Third edition, Harper and Row, 27, 306p.

Potter, P.E. and Pettijohn, F.J.,1977. Paleocurrent and basin analysis. $2^{\text {nd }}$ edition, Springer Verlag, Berlin, 413p. 
Saadallah, A. and Hassan, A.H., 1987. Sedimentological study of selected section of Tanjero Formation. Iraqi Jour. Sci., Vol.28, No.3 and 4, pp.483-506.

Sinclair, H.D., 1994. The influence of of lateral basin slopes on turbidite sedimentation in the Annot sandstone of SE France, Jour. of Sedimentary Research, Vol.64. No.1, pp.41-54.

Tucker, M. E., 1988. Techniques Sedimentology. Blackwell Publ. Co., 394p. 